\title{
SUSTAINABLE ECONOMIC GROWTH WITH WTO ACCESSION IN CHINA $^{1}$
}

\author{
DTÖ’NE KATILIM SONRASI ÇİN'DE SÜRDÜRÜLEBİLİR EKONOMIK BÜYÜME
}

\begin{abstract}
China's economy has grown remarkably since its adoption of market-oriented reforms in 1978. This reform movement played an important role in China's growth prospects, and is expressed in a transformation of its economic structure and economic growth model. The economic growth of China has further increased as a result of its accession to the World Trade Organization (WTO) on 11 December 2001, and through its economic openness. This has brought certain opportunities, but also presents risks. However, there is doubt about the issue of sustainability of China's long-term economic growth. This paper aims to examine the sources of economic growth in China through the literature on the subject, considering expansion of output, which is the sum of the change in consumption, investment, and net exports of goods and services, and then inward foreign direct investment (FDI), and their status as sources of economic growth. It concludes that despite China's rapid economic growth, there are a number of structural problems in the country's economy, as well as future challenges facing China.
\end{abstract}

Key Words: Economic growth, China, WTO

\section{$\ddot{O} \mathbf{z}$}

Çin, 1978 yılında piyasa odaklı reformların kabulünden bu yana önemli ölçüde büyümüştür. Ekonomik yapının ve ekonomik büyüme modelinin dönüşümü olarak ifade edilen bu reform hareketi büyüme beklentilerinde önemli rol oynamaktadır. Çin'in ekonomik büyümesi 11 Aralık 2001 tarihinde Çin'in Dünya Ticaret Örgütü (DTÖ)'ne katılımı ve ekonomik açıklıkla daha da artmıştır. Bu durum, birçok yönden bazı firsatlar getirmekle birlikte aynı zamanda riskler de getirmektedir. Ancak, Çin'in uzun vadeli ekonomik büyümesinin sürdürülebilirliği konusunda şüpheler bulunmaktadır. Bu çalışma, literatür incelemesi, tüketim, yatırım ve net ihracat ve ithalatın toplamı olarak çıktı artışı ve DYY aracılığıyla Çin'deki ekonomik büyümenin kaynaklarını incelemeyi amaçlamaktadır. Sonuç olarak, hızlı ekonomik büyümeye karşın Çin ekonomisinde yapısal sorunların olduğu ve gelecekte zorluklarla karşılaşabileceği sonucuna ulaşılmıştır.

Anahtar Kelimeler: Ekonomik büyüme, Çin, DTÖ

\footnotetext{
${ }^{1}$ This study is an improved version of Sustainable Economic Growth with WTO Accession in China presented at the Annual Conference on International Political Economy: Challenges to the Welfare State, Gediz University, May 23-25, 2012.

${ }^{2}$ Doç.Dr., Anadolu Üniversitesi, İİBF, İktisat Bölümü, msubasi@anadolu.edu.tr

${ }^{3}$ Yrd.Doç.Dr., Anadolu Üniversitesi, İİBF, İktisat Bölümü, msubasi@anadolu.edu.tr
} 


\section{Introduction}

The People's Republic of China was established in 1949 underthe Communist Party and Mao Tse-tung after the Communist Revolution. After it was clear that China could not maintain a centrally planned economic policy which it had long implemented, reforms were launched in 1978 to change the planned economic policy. The country took the first step to transform from a planned economy to a market economy in 1978 with Deng Xiaoping.

The transformation was achieved through economic reforms during the period 19781996, and the economy began to open out. The Third Plenum of the Eleventh National Party Congress Central Committee were adopted in December, 1978, to achieve political, economic, social, and cultural reforms ( China: The First Wave of Reform, 2014).

In 1978, the plan for reform was accepted to overcome instability in the economy. The reform was primarily implemented in urban areas. The transition strategy in China is termed 'a dual track reform' because of the dual character of the economy, with both a planned part and a market part. Understanding the evolution of this strategy will shed light on the reasons underlying structural problems of the Chinese economy.China preferred gradualism to more radical reform approach due tothe reasonable economic conditions at the time of the initial adoption of the reforms (Yueh, 2003:3).

Through this process, the country experienced three historical economic transformations. These transformations were from a planned economy to a market economy, from economic development ofa substantially subsistence peasant economy to an industrialized economy and economic globalization, and from autarky to the role of an important player with a global production network. The process of economic transformation has largely been realized in the form of free agricultural markets being permitted in agriculture in 1979. The economic development process began seriously in 1984 when the government allowed the establishment of private industrial enterprises in rural areas. Finally, economic globalization legislated for in 1984 when free trade and liberal foreign investment policies were extended from the four special economic zones to fourteen other coastal cities (Sachs and Woo, 2002:2).

China's economic growth rate has been questioned in recent years,and doubts surround whether this growth rate is sustainable over the medium to longer term. The objective of this study is to examine the expansion of China's output and its sustainability. For this purpose,the paper is organizedas follows. The first and second sectionsprovide a brief review of the economic performance of China after itsaccession to the WTO. The third section analyzesthe expansion of outputand inward FDI as sources of economic growth. The fourth section summarizes the growing imbalances and challenges for China's future growth, and the final section concludes with a number of proposals to promote sustainable economic growth.

\section{Economic Performance of China}

China has emerged as a key player in the global economy since its adoption of market oriented reforms in 1978. Economic growth and export have increased significantly in China after this process.

\subsection{Economic Growth}

In the world economy, no other countries have been able to grow or increase the living standards of their citizens as fast as China has done in the last quarter of the twentieth century. Leaving the conservative and rigid policies after the Cold War, China benefited from its existing capacity and the opportunities presented by globalization (Sandikl1, 2010:40).The 
internationalization of the Chinese economy is extremely impressive. The Chinese economy has experienced an extensive transformation, especially during the last two decades. The economic reforms of 1978 have led to high economic growth and rapid industrialization in China. China's economic growth has averaged ten percent for three consecutive decades. Thisreform movementis notonly thetransition froma plannedeconomyto a market economy,but alsothetransformation ofeconomic structureand of an economicgrowth model. China'scontinued economic transformationhas had a profound effect, not only on China, but on the entire world.

China has become a world economic superpower. It has the second largest national economy and is the largest exporter worldwide. Figure 1. shows that the United States are the leading economy with a total GDP of 16.800 billion USD, and China is ranked second with a total GDP of 16.158 billion USD, according to figures for 2013. The top five countries include the United States, China, India, Japan and Germany, based on annual GDP.

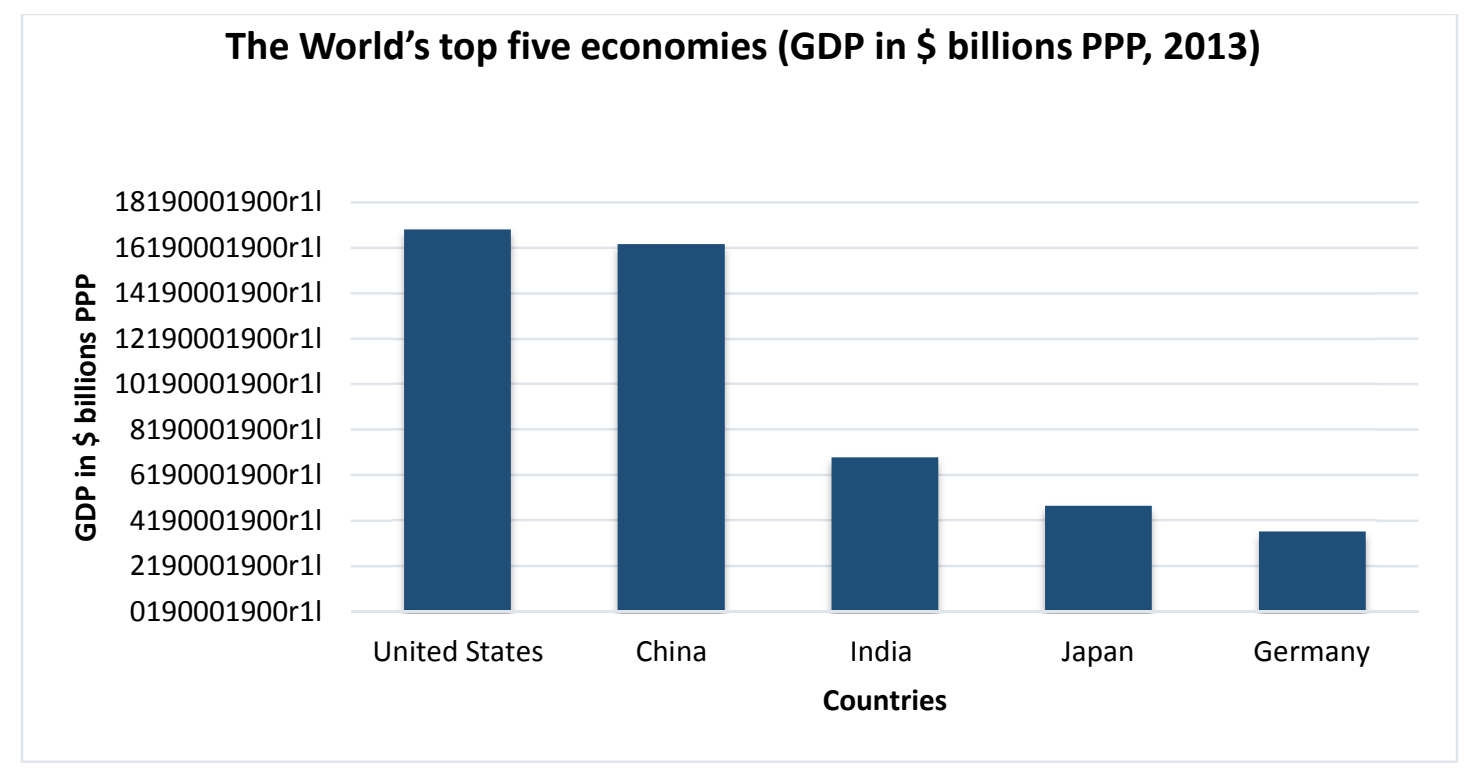

Figure 1. The world's top five economies (GDP in \$ billions PPP, 2013)

This figure is created by the authors according to data of the World Bank, accessed on September 16, 2014, http://data.worldbank.org/indicator

China's GDP has noticeably increased during the reform period. Figure 2 shows that China enjoyed sustained growth in the 1980s and the 1990s. Although this growth slowed in the late 1990s, the rate of growth was 7 per cent in 2001 (Wu, 2004:1) and 7.7 per cent in 2013. 


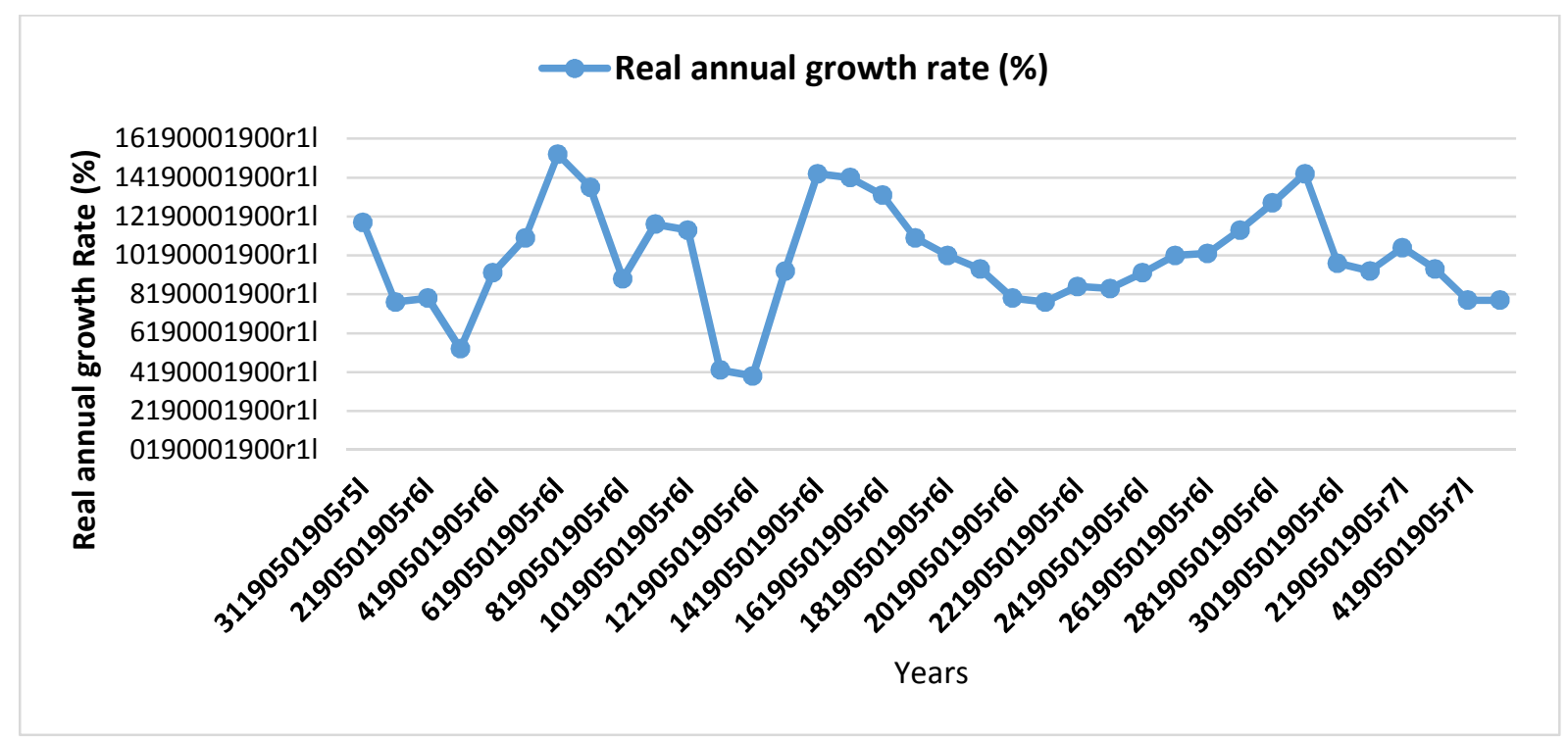

Figure 2. China's economic growth rate (\%) (1978-2013)

This figure is created by the authors according to data of the World Bank, World DataBank/World Development Indicators, accessed on September 16, 2014, http://databank.worldbank.org/data/views/reports/tableview.aspx

Real GDP growth, accompanied with foreign investment into China, and non-state enterprises developed accordingly (Chinability, China's economy.., 2012). Institutional reforms of China and openness to trade and investment seem to be playing a key role in growth and poverty reduction in the first stages of reforms. Almost all of the institutional experiments were applied in the early 1980s. The economic structure of China transformed, from an agrarian economy in the 1980s, to a manufacturing economy (Zhao and Wang, 2009:179).

The share of primary industry in GDP fell from 28\% in 1978 to $10 \%$ in 2013. Agricultural output grew more slowly than the output of other economic sectors. At the same time, the share of tertiary industry grew from $24 \%$ to $46 \%$ as the services sectors proliferated. The share of the secondary sector has remained level at around $45 \%$ over the whole period, as can be seen in Figure 3. 


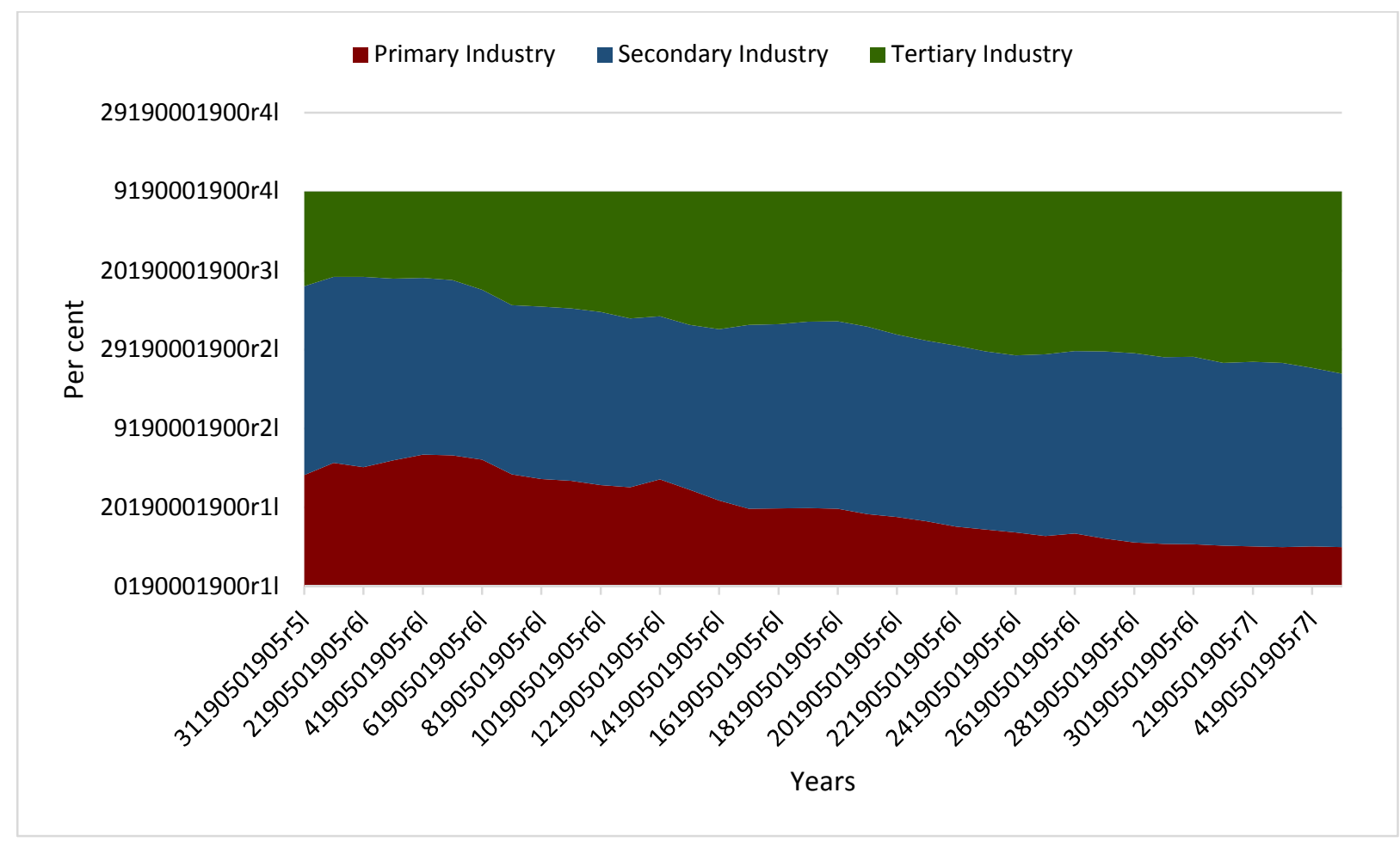

Figure 3. Structural transformation in China (\%)

This figure is created by the authors according to data of the World Bank World DataBank/World Development Indicators, accessed on September 16, 2014.

http://databank.worldbank.org/data/views/reports/tableview.aspx?isshared=true

However, China was affected by the global economic crisis emanating from industrialized countries. Owing to weak external demand, exports and imports declined in the second half of 2008, and in the first quarter of 2009. Unemployment rose dramatically. Concerns have risen about the rapidly growing current account surplus, continuing imbalances among the primary, secondary and tertiary sectors, rising income inequality between urban and rural households, a declining share of domestic consumption in GDP, environmental degradation, and sustainability issues. (Zhao and Wang, 2008:179-180).

\subsection{Promotion of Trade}

WTO (World Trade Organization) accession in 2001 heralded a new step for China. It created modern and international best-practice institutions, and laws and regulations conformingto WTO rules for China. WTO accession and subsequent reforms have changed the investment climate in China. Making investments have become more secure, transparent, rules-based, and law-binding. Thus, imports and exports have grown, and more foreign direct investment has been attracted into the country. Total trade has expanded and China's export structure has been upgrading rapidly since China's accession (Zhao and Wang, 2009:179).

As one of the fastest growing nations since its WTO accession, China's role in the world economy has also increased (Xiaomei, 2009:544). It has become the largest world trader. The total value of Chinese world exports in 2012 was estimated to be roughly $\$ 18.816$ trillion US Dollars (USD). Of this, China takestop spot among nations, with a total export value of about $\$ 2.209$ trillion USD. The United States follows China, with a combined export value of $\$ 1.580$ trillion USD. Germany comes in third, exportinggoods to the value of $\$ 1.453$ trillion USD. These three countries exported \$5.242 trillion USD worth of goods, a little less than one-third of the world's export value, as can be seen in Table 1. 
These figures are especially interesting when compared to the total value of these nations' imports. Table 1 shows that the United States is the largest importer, with total imports of around \$2.329 trillion USD. China and Germany follow the United States, with imports of \$1.950 trillion USD and \$1.189 trillion USD, respectively. This means that these three countries import about $\$ 5.468$ trillion USD worth of goods, roughly equal to their total exports, but with a greater amount carried by the United States.

Table 1. Leading Exporters in World Merchandise Trade, 2013

(Billion Dollars and Percentage)

\begin{tabular}{|l|l|l|l|l|l|l|l|}
\hline Rank & Exporters & Value & Share & Rank & Importers & Value & Share \\
\hline 1 & China & 2209 & 11.7 & 1 & United States & 2329 & 12.3 \\
\hline 2 & United States & 1580 & 8.4 & 2 & China & 1950 & 10.3 \\
\hline 3 & Germany & 1453 & 7.7 & 3 & Germany & 1189 & 6.3 \\
\hline 4 & Japan & 715 & 3.8 & 4 & Japan & 833 & 4.4 \\
\hline 5 & Netherlands & 672 & 3.6 & 5 & France & 681 & 3.6 \\
\hline
\end{tabular}

Source: World Trade Organization, International Trade Statistics 2014:26, accessed on September 16, 2014, http://www.wto.org/english/res_e/statis_e/its2014_e/its14_world_trade_dev_e.pdf

\section{Entering the WTO for China}

The WTO was created on 1 January 1995, replacing the General Agreement on Tariffs and Trade, which had been formed in 1948. The WTO stresses the central role of markets and private enterprise. Its main function is to ensure that trade flows as smoothly, predictably and freely as possible. The WTO is the only international agency overseeing the rules of international trade. (Ching, Hsiao and others, 2011:285).

After fifteen years as a candidate, China's application for membership of the World Trade Organization (WTO) was accepted at the WTO's Doha ministerial meeting in November 2001(Bhattasali, Li and Martin, 2004:1), and China then formally joined the WTO.

Regarding conditions for joining the WTO, China agreed to:

(a) A reduction of average import tariff from 24.6 to 9.4 per cent:

- From 22 to 17.5 percent for agricultural products; elimination of subsidies for exports of agricultural exports.

- From 25 to 8.9 percent for industrial products; from 100 to 25 percent for vehicles, and 10 percent for vehicle parts by 2006, and from 12.5 to 3.4 percent (2002) and zero (2005) for information technology products.

(b) Farm subsidies to be capped at 8.5 of production value.

(c) Elimination of import tariffs on computers, semiconductors and other high-tech products by 2005.

(d) Elimination of quotas by 2006.

(e) Substantial opening of service sectors, including banking, insurance, telecommunications and professional services:

- Up to 49 percent foreign ownership in telecommunications and insurance after three years.

- Importers to have their own distribution networks. 
- Full market access for foreign banks within five years (currency business with local enterprises after two years) (Ching, Hsiao and others, 2011:286).

The accession of China fits within the context of the five fundamental principles of the GATT and the WTO. These principles are nondiscrimination, market openness, transparency and predictability, undistorted trade, and preferential treatment for developing countries (Bhattasali, Li and Martin, 2004:25). The entry to the WTO has affected every aspect of China. The country has removed trade barriers and opened its markets to foreign companies after WTO membership. Family-based Chinese farms now face competition from large, modern and well-equipped US farms. Reduced tariffs could expose many previously protected sectors to foreign competition (Ching, Hsiao and others, 2011:286).

China's WTO membership has affected the structure of the Chinese economy and thus, the sustainability of its growth.

For China, manufactured goods account for over $90 \%$ of merchandise exports. China is the largest exporter of manufactured products in the developing world. Its exports span a broad range of technologies and are rapidly diversifying and upgrading (Yueh, 2003:10). Trade volumes for China place it as the largest world exporter in 2014.

First on trade policy, China is already a strong international competitor in a large range of industrial products, led by simple labor-intensive manufactures, but quickly diversifying into complex, capital and technology-intensive goods. (Yueh, 2003:11).

\section{Sources of Economic Growth}

In all economies, the expansion of output is the sum of the change in three components: consumption (private and government), investment, and net exports of goods and services (Bergsten, Lardy and Mitchell, 2009:106).

\subsection{Consumption}

The growth of household and government consumption has been rapid in the reform period. In Figure 4, it can be seen that household consumption averaged just over half of GDP in the 1980s. This share became an average of 47 percent in the 1990s. Household consumption as a share of GDP fell sharply after 2000. It accounted for 36 percent of GDP in 2007 and only 34 percent of GDP by 2013.

Government consumption as a share of GDP was around 14 percent throughout the reform period, around 16 percent in 2001, 13.3 percent in 2010 and at 14.4 percent in 2013.

Consequently, the relative importance of consumption as a source of growth during the past two decades has decreased substantially. In the first half of the 1980s, consumption growth accounted for almost four-fifths of the economic expansion of China, whereas since 2003, this share has fallen to less than two fifths (Bergsten, Lardy and Mitchell, 2009:108). 


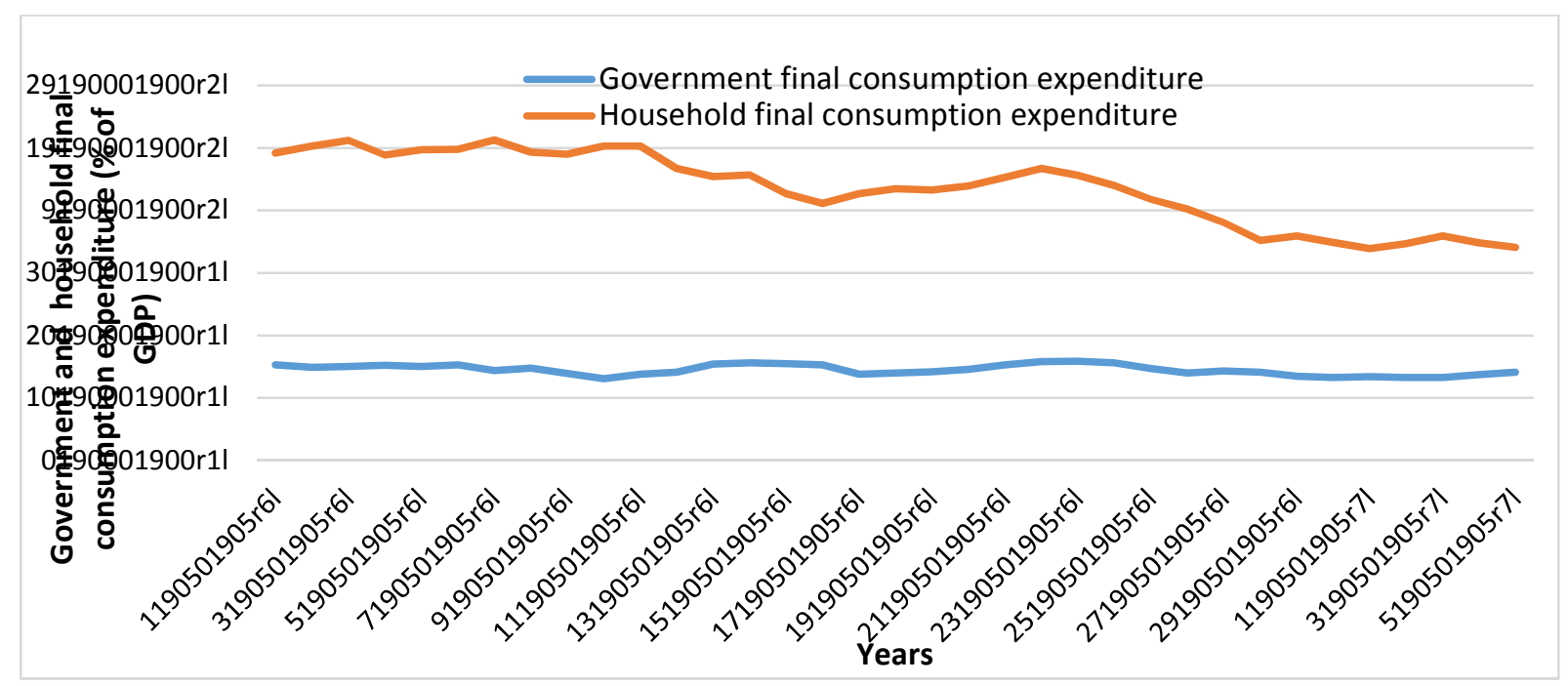

Figure 4. Household and general government final consumption expenditure ( $\%$ of GDP)

(1978-2013)

This figure is created by the authors according to data of the World Bank, World Development Indicators, accessed on September 21, 2014, http://databank.worldbank.org/data/views/reports/tableview.aspx

\subsection{Investment}

Capital accumulation (investment) was important, while a sustained increase in productivity was the driving force behind China's recent economic growth. New machinery, better technology, and more investment in infrastructure have caused arise in output. Capital formation accounted for over 65 percent of pre-1978 growth, with labor adding another 17 percent, together accounting for only 58 percent of the post- 1978 boom, a slide of almost 25 percentage points (Hu and Khan, 1997). In Figure 5, the gross capital formation rate can be seen at around 35 percent of GDP in the first decade of economic reform. Since the beginning of the 1990s, China's average investment rate has been higher andin 1993, and again between 2003 and 2013,it exceeded 40 percent of GDP. China's investment rate also increased during this process. Rising investment was particularly important after 2001, contributingto almost half of China's economic growth.

China has one of the highest investment rates in the world at around 40 percent of GDP. Investment hasbeen directed mostly into manufacturing (30 percent), infrastructure (18 percent), and the real estate sector(23 percent). It is financed primarily through retained earnings and bank loans. Therefore, approximately one third of investment is connected to the expansion of the tradable sector (Guo and N'Diaye, 2009:5). 


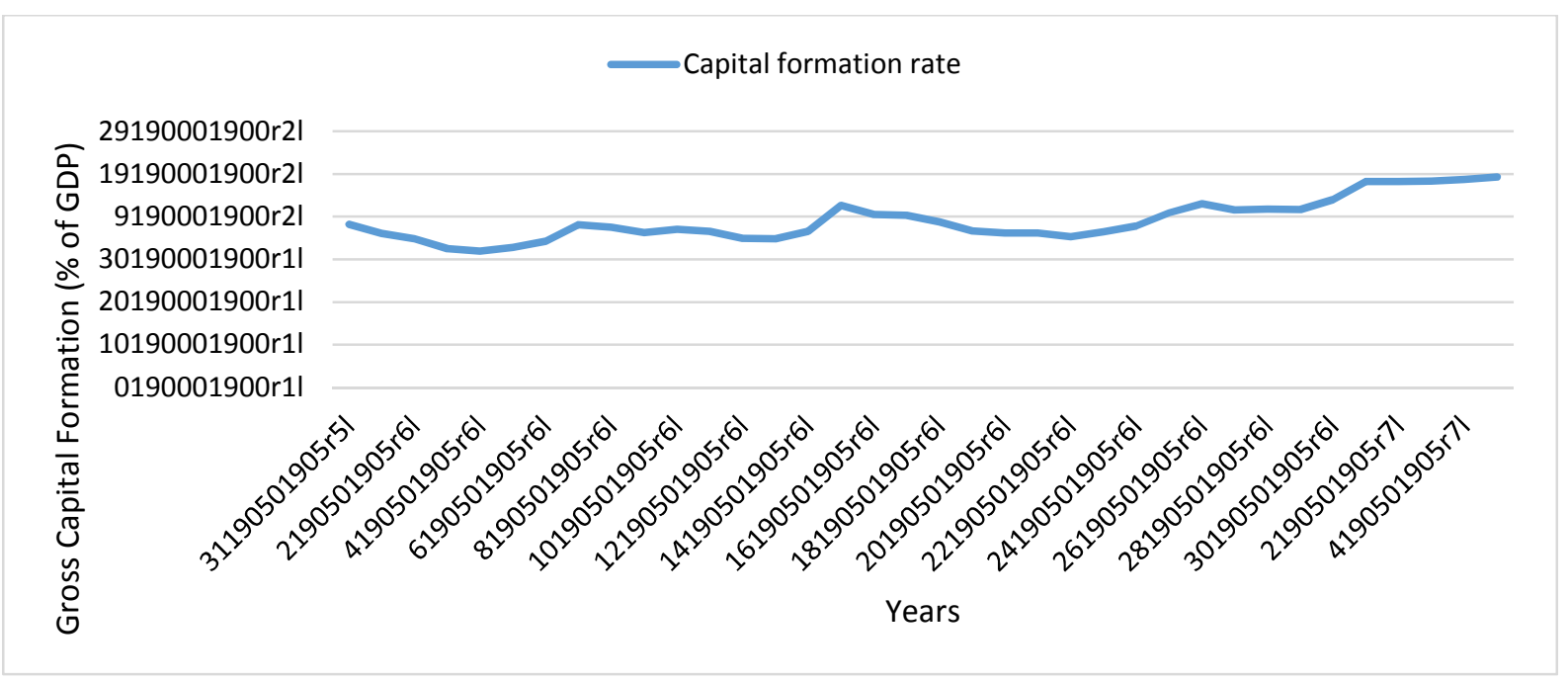

Figure 5. Gross Capital Formation rate (\% of GDP) (1978-2013)

This figure is created by the authors according to data of the World Bank,World Development Indicators, accessed on September 21, 2014, http://databank.worldbank.org/data/views/reports/tableview.aspx?isshared=true

\subsection{Net exports of goods and services}

Agarwal and $\mathrm{Wu}$ evaluate three basic principles (uniformity, transparency and judicial reviewability) concerning the trade administration system that the WTO framework includes. "This means that China must ensure that the provisions of the WTO agreement are applied uniformly across all of its customs territory, including at sub-national level. Second, China will make its laws and regulations affecting foreign trade readily available to other WTO members, individuals and enterprises, thus ensuring transparency. Third, China will make its trade administration actions subject to prompt judicial review. China has agreed to establish independent tribunals, contact points and procedures for the prompt review of all administrative actions by the Chinese government with respect to trade-related laws and regulations" (Agarwal and Wu, 2003:280).

During the 1990s, China made substantial progress in reducing the coverage of nontariff barriers, lowering tariffs, and abolishing trade distortions created by the exchange rate regime (Bhattasali, Li and Martin, 2004:213). WTO membership and commitments have been a catalyst for trade policy reform and increasing openness, and have also improved access to the foreign markets of the country. A reduction of tariffs, together witha reduction of non-tariff barriers to trade, and inbound Foreign Direct Investment, has improved the competitiveness of China. There has been a rapid expansion in the volume of imports and exports, resulting in outstanding economic growth. (Xiaomei, 2009:543). Consequently, the growth of exports of goods and services has been a major source of economic growth for China. As can be seen in Figure 6, while the export of goods and services was 6.6 percent of GDP in 1978, it reached 20.2 percent of GDP in 1995, 37.1 percent of GDP in 2005 and 26.4 percent of GDP in 2013. On average, between 1978 and 2013, the expansion of exports accounted for 20.8 percent of GDP and for 30.7 percent of GDP in the period 2001-2013, following admission tothe WTO.

On the production side, exports now contribute over 30 percent in terms of value added to output growth, which is up from 15 percent in the 1990s. This large contribution reflects a rapid growth in exports and also an increase in the domestic content of these exports. This has led to a substantial expansion of China's global market share (Guo and 
N'Diaye, 2009:5). As can be seen in Table 1, China's exports accounted for around 12 percent of world trade in 2013.This means that China is one of the most trade-dependent countries in the world.

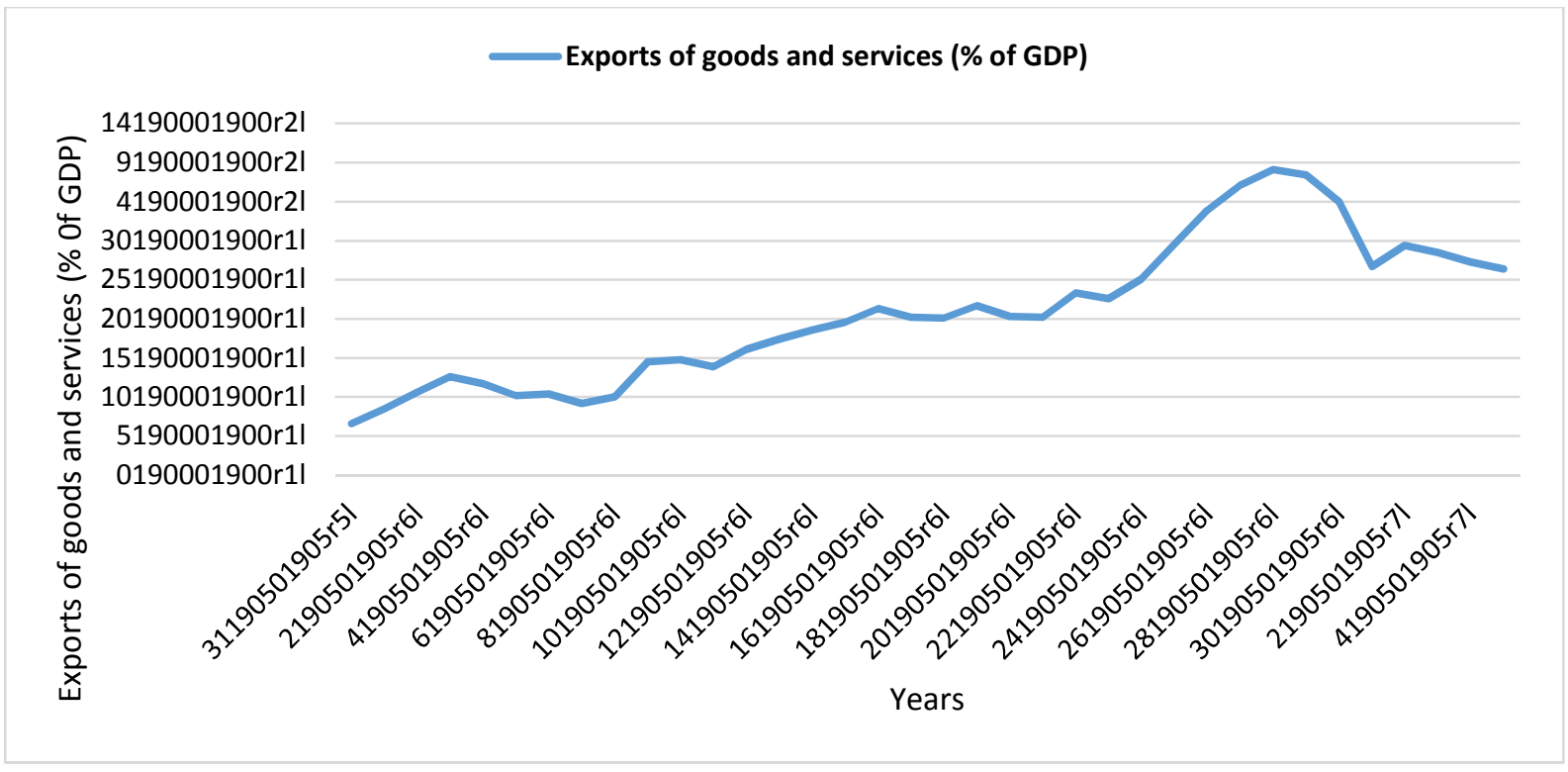

Figure 6. Exports of goods and services (\% of GDP) (1978-2013)

This figure is created by the authors according to data of the World Bank, World Development Indicators, accessed on September 25, 2014, http://databank.worldbank.org/data/views/reports/tableview.aspx?isshared=true

In Figure 7, the net exports of goods and services in 1995 was over 2 percent, and in 2005 this figure more than doubled to 5.5 percent of GDP. In 2007, the figure reached 8.8 percent of GDP. On average, between 2005 and 2010, the expansion of net exports accounted for 6.3 percent of GDP. The exports of goods and services and investment together accounted for around $76 \%$ of GDP in 2013.

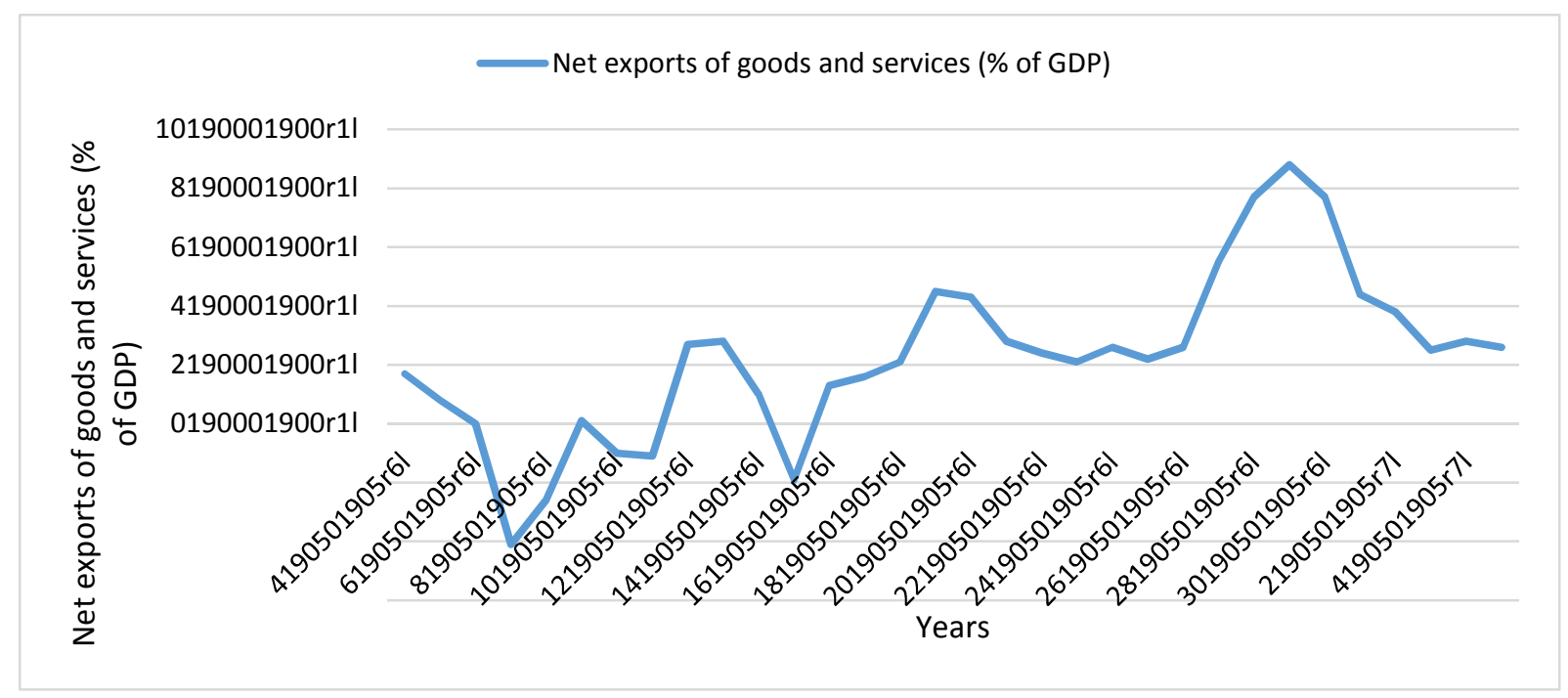

Figure 7. Net exports of goods and services (\% of GDP) (1978-2013)

This figure is created by the authors according to data of the World Bank, World Development Indicators, accessed on September 25, 2014, http://databank.worldbank.org/data/views/reports/tableview.aspx?isshared=true

To sum up, as seen in Figure 8 consumption as a share of GDP has continued to fall, and its contribution to China's economic growth has been modest. On the other hand, net 
exports of goods and services have soared, both literally and as a share of GDP, and thus their contribution to economic growth is currently significant. (China's Rise.....)

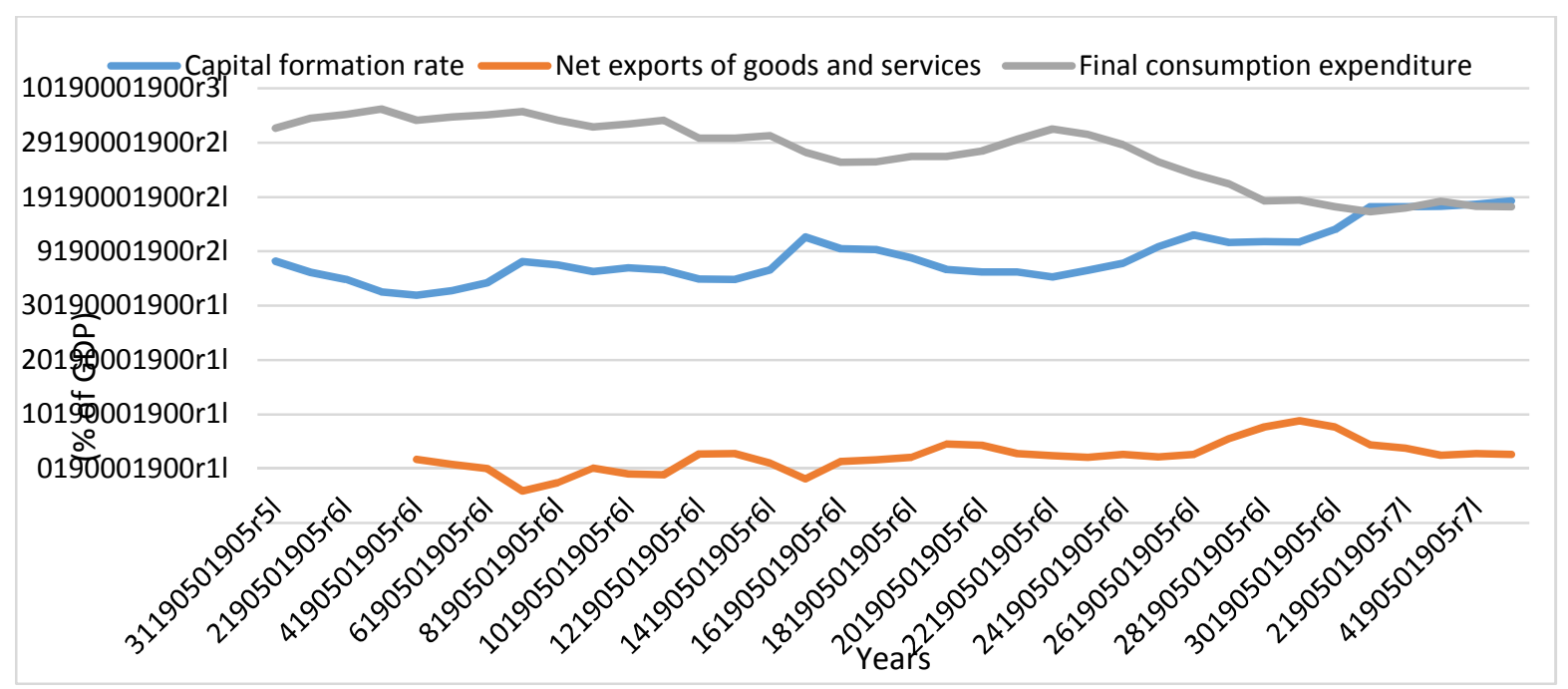

Figure 8. China's consistent decline in consumption (1978-2010) (percent of GDP)

This figure is created by the authors according to data of the World Bank, World Development Indicators, accessed on September 25, 2014, http://databank.worldbank.org/data/views/reports/tableview.aspx

\subsection{Foreign Direct Investment}

China's entry to the WTO has also attracted more foreign direct investment. The efficient allocation of production factors through increased specialization, according to China's comparative advantages, a more rapid physical capital accumulation and a rapid growth of factor productivity due to technology transfer, has been effective in this result (Ma and Wang, 2001 cited by Agarwal and Wu, 2003:281).

Despite a lack of full capital account convertibility, China had become, by the mid$1990 \mathrm{~s}$, the second largest host country for foreign direct investment after the U.S. and the largest among developing countries (Yueh, 2003:10).Cumulative foreign direct investment reached nearly US\$100 billion in 1994; annual inflows increased from less than 1 percent of total fixed investment in 1979 to 18 percent in 1994 (Hu and Khan, 1997).

Foreign investment has been an important factor in the Chinese economy. China has used the opportunities and skills that foreign direct investment brings to identify and develop productive investment projects (Naughton, 2007:145), building factories, creating jobs, linking China to international markets, and leading to important transfers of technology $(\mathrm{Hu}$ and Khan, 1997). Foreign investors have also been major drivers of China's export success, and this trend can be expected to continue for the foreseeable future.

China has gradually opened its doors to foreign direct investment since its economic reforms. In the early stages, the opening-up policies were limited to certain special cities, such as the special economic zones (SEZs) and opening coastal cities (OCCs). This stage (prior to 1991) is characterized by a slow increase in the absolute amount of FDI. The difficulty in entering the Chinese market and the non-convertibility of the Chinese Yuan were possible barriers to foreign investment (Hong, 2008; 136). China's trade and investment reforms and incentives led to a surge in FDI beginning in the early 1990s. Such flows have been a major 
source of China's productivity gains and rapid economic and trade growth (Morrison, 2012:10). 1992 to 1998 witnessed a substantial increase in foreign capital flowing into China. The annual inflow of FDI increased sharply after 1992. However, the rate of increase slowed in 1997, and the absolute amount even decreased in 1998. (Hong, 2008:136). The composition of FDI inflows was also changing.

According to WTO accession agreements, China needs to give foreign companies full accession to the domestic market (Lin, 2004:21).Foreign investors are allowed to invest in some sectors that were previously highly restricted. In order to comply with WTO rules, the Chinese government has to accelerate legislative and institutional reforms, make polices stable and predictable, remove special protection on SOEs, in accordance with equal competition, and create an impartial, competitive environment with unified market regulations (Jiang, 2006:4). These changes may significantly impact the location preferences of foreign investors. (Hong, 2008:136-137).In Figure 9, it can be seen that foreign direct investment was 0.2 percent of GDP in 1982, reaching 6.0 percent of GDP in 1994 and 3.8 percent of GDP in 2013.

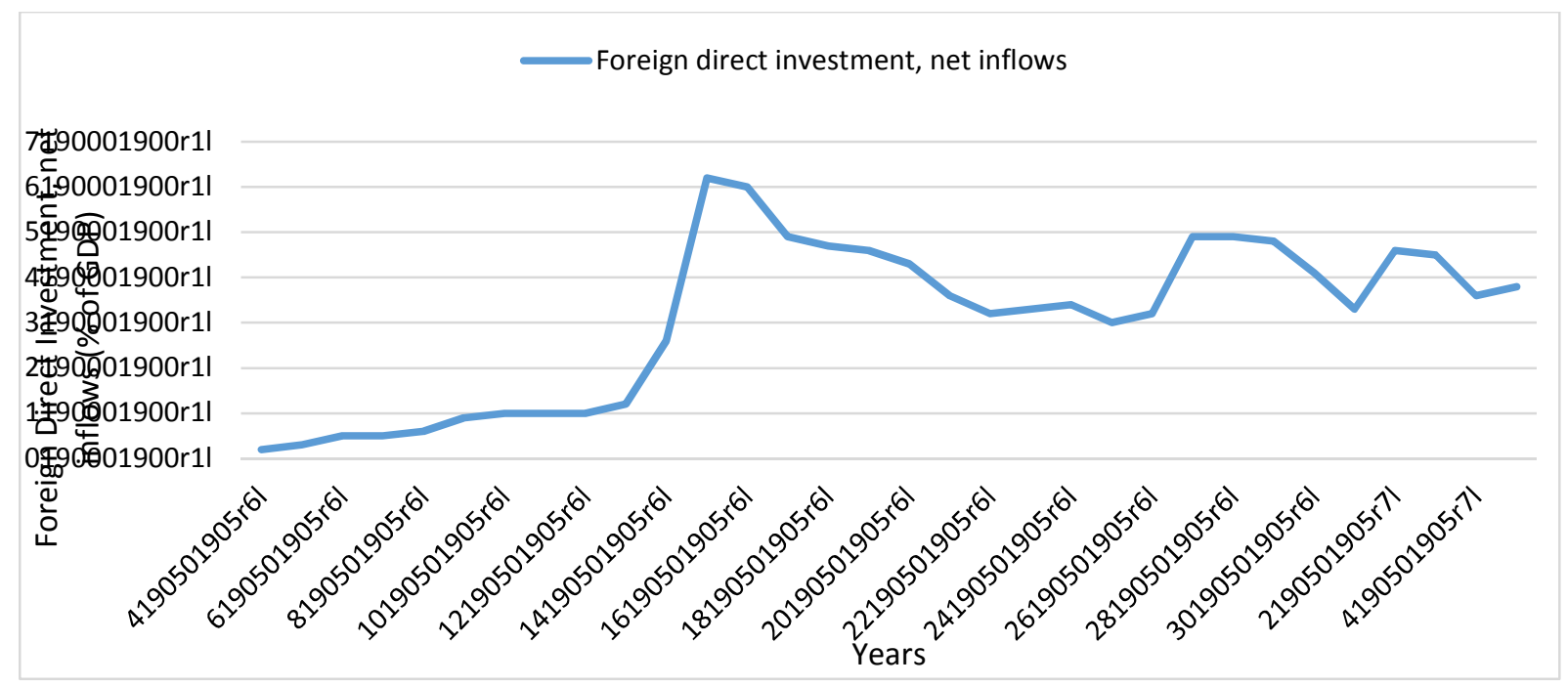

Figure 9. Foreign Direct Investment, net inflows (\% of GDP)

This figure is created by the authors according to data of the World Bank, World Development Indicators, accessed on September 25, 2014, http://databank.worldbank.org/data/views/reports/tableview.aspx

The most prominent contribution of FDI is the expansion Chinese exports. The export performance of FDI firms from 1980 to 2013 increased. China's FDI policy has been deliberately biased towards export-oriented FDI. As a result, FDI firms have rapidly become a major exporting group (Chen, 2011:16). More than half of FDI in China comes from Asian countries (or regions), including Hong Kong, Japan, South Korea, and Taiwan. After China's WTO accession agreement with the USA in 1999, there have been substantial changes with multinational enterprises (MNEs). An increasing proportion of FDI comes from the USA and Europe, flowing into eastern China, witha decreasing share from Asian-based FDI. All of the foreign-owned enterprises have replaced joint ventures to become a main ownership mode (Hong, 2008; 138). In summary, the remarkable economic growth of China has been driven largely by exports and investment, which were boosted significantly because of WTO driven liberalization since 2001 (Xiaomei, 2009:545).

\section{Challenges for the Future Growth of China}

Although the Chinese economy has been remarkably successful since reform, recent indicators have begun to cast doubt on the sustainability of its growth (Yueh, 2003:2). China 
faces a number of challenges to overcome in the new era in order to achieve better sharedequitable and sustainable growth. The following are the some of the challenges in the sequence pursued by China (Zhao and Wang, 2009:193-198):

-The service sector in China is lagging behind both industrialized and developing countries. This leads to a lack of competition and low levels ofmarketization. It is important to open the sector up to domestic and foreign competition.

-China's issues of sustainability are not historically linked to private consumption as they are in the United States or Western Europe. They are linked to the industrial processes that are supporting China's economic development model. As mentioned earlier, China's economic growth is dependent on investment and net exports, and the private consumption share of GDP has decreased in the past decade.

-Adecline in household income is the main cause for the decline in consumption share.Despite the remarkably high national economic growth, Chinese household incomes have declined across all major sub-categories of wages, investment incomes, and government transfers.

-Job creation in China has been relatively slow in contrast to the soaring GDP growth.In addition to the problem of unemployment in the countryside, unemployment amongst the urban population is rapidly growing. Low employment levels lead to low disposable household incomes.

-Growing income inequality is another problem. While economic growth has brought unprecedented prosperity to China, income inequality has experienced a noticeable increase.

-China has consistently maintained a rising surplus in both Current Account and Capital and Financial Account since 1994. The decline of domestic consumption, the export-oriented development strategy, and the expectation of the RMB (ChineseYuanRenminbi)appreciation after the change in China's exchange rate regime in July 2005 are the fundamental factors.

-China's economic transformation has focused on GDP growth since 1978. However, now China must make a number of fundamental readjustments to guarantee economic sustainability. China's rapid economic growth relied mainly on capital inflows, inputs of natural resources and cheap human resources. These factors may negatively affect income inequality, environmental degradation and social injustice. Thus, China should stress quality of growth as an economic strategy. The key will be to abandon the expansive growth style and turn to market-oriented sustainable growth (Honghua, 2004:3-4).

Looking at sustainability issues in China today, the largest pressure China faces in solving sustainability issues comes from within. External pressures, or concerns about the planet as a whole, are secondary. As has been seen in recent years, China's ability to manage stable growth and create a balance between the economy, the environment and society has proven limited (Wong, 2010).

Problem areas include institutional, social and issue-related factors, 'potential for conflict' areas, and international issues. China's economic growth depends on its ability to overcome these challenges (Honghua, 1994:7)

\section{Conclusion}

After fifteen years of negotiations, China joined the World Trade Organization (WTO) in 2001. This has meant new opportunities, but has also created risks as China increases its integration into the global economy. Trade and investment liberalization under the WTO causes greater competition between Chinese and foreign firms. 
China's economic growth has averaged 10 percent for three decades. Though this growth has slowed in some years, it still achieved a rate of 7 per cent. China's top leaders are expecting that China's GDP growth rate will be around 8 percent for the next thirty years. This prediction is based on favorable major indicators and technological knowhow that China can adapt from advanced countries at a lower cost,in order to achieve the necessary technological innovation for economic growth.

The remarkable economic growth of China has been driven largely by exports and investment, which have been boosted significantly because of the WTO driven liberalization since 2001. Consumption as a share of GDP has declined, and its contribution to China's economic growth has been limited. The most immediate explanation for China's rapid growth has been the very high rate of investment. Rising investment was particularly important after 2001 ; it contributed to almost half of China's economic growth. On the other hand, net exports of goods and services have increased as a share of GDP, and their contribution to economic growth has been significant.

Promoting more sustainable economic growth in China, Chinese political leaders propose to rebalance the sources of economic growth. They have approved a growth based on expanding domestic consumption, instead of investment and export-led growth.

Insufficient demand and excessive production may be confronted in China in the process of sustaining this trend. This kind of economic growth is unsustainable and limited. The export-oriented growth of the Chinese economy makes it vulnerable to global fluctuations. Exports, and therefore economic growth, are adversely affected by global crises. Therefore, policies to stimulate domestic demand are important for sustainable economic growth.

Besides the differences between urban and rural areas in China, it has become apparent that the wealth gap between rich and poor is enormous. This imbalance results from many factors, such as incomplete agricultural and economic reforms, economic development, and educational differences between regions.

Foreign direct investment has also been an important factor in China's economic growth. China has used the opportunities and skills that foreign direct investment brings. China has also developed productive investment projects linking China to international markets, leading to important transfers of technology. The most prominent contribution of FDI is the expansion of Chinese exports. The export performance of FDI firms from 1980 to 2013 has increased. China's FDI policy has been deliberately biased towards export-oriented FDI. However, as a result of this export-oriented strategy, most foreign direct investment has been invested in processing industries, and more than half of Chinese imports are for either processing or reexport purposes.

Although the Chinese economy has been remarkably successful since reform, China has a number of challenges to overcome in the new era. China's economic transformation, focusing on GDP growth, has negatively affected income inequality, environmental degradation, and social injustice. Thus, China should stress quality of growth as an economic strategy. Problem areas include institutional, social and issue-related factors, 'potential for conflict' areas, and international issues. China's economic growth depends on its ability to overcome current challenges. 


\section{References}

Agarwal, James and Wu,Terry (2004). China's entry to WTO: global marketing issues, impact, and implications for China, International Marketing Review, Vol. 21 No. 3, 279300, ErişimTarihi: 14.11.2014, http://econ3.upm.edu.my/kelasmaya/sumberkursus/A01960/MGM4136\%20EX/CHINA.p df

Bergsten, C. Fred Lardy, Nicholas R. Mitchell and Derek J. (2008). China's Rise: Challenges and Opportunities, Washington, DC: Peter G. Peterson Institute.

Bhattasali, Deepak Li, and Martin, Will (2004). Impacts and Policy Implications of WTO Accession for China', China and the WTO: Accession, Policy Reform and Poverty Reduction Strategies, Washington: World Bank and Oxford University Press.

Chen, Chunlai (2011). Foreign direct Investment in China: Location, Determinants, Investor Differences and Economic Impacts, Massachusetts, USA: Edward Elgar Publishing, Inc.

China, The First Wave of Reform, 1979-84 (2014), ErişimTarihi: 02.10.2014, http://lcweb2.loc.gov/cgi-bin/query/r?frd/cstdy:@field(DOCID+cn0305)

Chinability (2012). China's economy in figures, GDP growth in China 1952-2011, ErişimTarihi: 02.10.2014, http://chinability.com/GDP.htm

Ching, H. Steve, Hsiao, Cheng and others.( 2011). Economic Benefits of Globalization: The Impact of Entry to the WTO on China's Growth, Pasific Economic Review, 16:3, 285301.

GDP Growth in China 1952-2011. ErişimTarihi: 15 September 2014, http://www.chinability.com/GDP.htm

Gunde , Richard (2004). Hong Kong and Political Change in China: Let the Small Teach the Big, Ucla International Institute,ErişimTarihi: 10.12.2014, http://www1.international.ucla.edu/article.asp?parentid=15856

Hong, Junjie (2008). WTO accession and foreign direct investment in China, Journal of Chinese Economic and Foreign Trade Studies Vol. 1, No.2, 136-147.

Honghua, Men (2004). A Sustainable Chinese Economy?,The Rise of China and a Changing East Asian Order (KokubunRyosei and Wang Jisi, Edt.), Exchange, Tokyo: Japan Center for International, ErişimTarihi: 10.12.2014, https://catalog.lib.uchicago.edu/vufind/Record/5604564/TOC

Hu, Zuliu and Khan, Mohsin S. (1997 June). Why Is China Growing So Fast? Economic Issues, IMF, No.8.

-Jiang, Chun. A Re-examination of Technology Transfer in Sino-foreign Joint Ventures after China's WTO Accession, Journal of American Academy of Business, ErişimTarihi: 06.11.2014, http://papers.ssrn.com/sol3/papers.cfm?abstract_id $=893400$

Lardy, Nicholas R. (2007 May) The China Balance Sheet in 2007 and Beyond, Center for Strategic and International Studies and the Peterson Institude for International Economics, ErişimTarihi: 12.10.2014, http://www.iie.com/publications/papers/lardy0507.pdf

Lin, Justin Yifu (2004). Is China's Growth Real and Sustainable? Asian Perspective, Vol.28, No. 3, 5-29.

Ma, J. and Wang, J. (2001, March-April). Winners and losers of China's WTO entry, The China Business Review, 22-5cited by AgarwalJames and Wu, Terry (2004). China's entry 
to WTO: global marketing issues, impact, and implications for China, International Marketing Review, Vol. 21 No. 3, 279-300, ErişimTarihi: 14.11.2014, http://citeseerx.ist.psu.edu/viewdoc/download?doi=10.1.1.473.6960\&rep=rep1\&type=pdf

Morrison, Wayne M. (2012, June 26). China's Economic Conditions, CRS Report for Congress, Congressional Research Service,ErişimTarihi:

06.11.2014,http://fpc.state.gov/documents/organization/194783.pdf

Naughton, Barry (2007). The Chinese Economy: Transitions and Growth, London: The MIT Press.

Sachs, Jeffrey D. and Woo, Wing Thye. (2002, September). China's Economic Growth After WTO Membership, Journal of Chinese Economic and Business Studies, Vol.1, No.1, , 131, ErişimTarihi:

02.10.2014)http://www.tandfonline.com/doi/pdf/10.1080/147652803200003972131,http:/ /www.earth.columbia.edu/sitefiles/file/about/director/pubs/China_CBB03.pdf

Sand1kl1, Atilla (2010). China A New Superpower? Dimensions of Power, Energy, and Security, İstanbul: Bilgesam.

The Future of the Greater China Economy, UCLA International Institute Asia Institute, http://international.ucla.edu/asia/article/21291?AspxAutoDetectCookieSupport=1

The World Bank, World DataBank/World Development Indicators, ErişimTarihi: 16.09.2014, http://databank.worldbank.org/data/views/reports/tableview.aspx

Wong, Calvin (2010, November 14). Is China's Growth Sustainable? The Diplomat, ErişimTarihi: 15.10.2014,http://thediplomat.com/2010/11/is-chinas-growth-sustainable/

World Trade Organization, International Trade Statistics 2014, (ErişimTarihi: 16.10.2014), http://www.wto.org/english/res_e/statis_e/its2014_e/its14_world_trade_dev_e.pdf

Wu, Yanrui (2004). China's Economic Growth: A miracle with Chinese Characteristic, New York: Routledge Curzon.

Yueh, Linda (2010). The Economy of China, Cheltenham: Edward Elgar Publishing Inc.

Yueh, Linda (2003, May). China's Economic Growth with WTO Accession: Is it Sustainable? Asia Programme Working Paper, No.1.

Xiaomei, E. (2009, June). China's WTO Accession and Sustainable Development: Challenges and Policy Responses, Journal of World Trade, Vol. 43, No.3, 541-569.

Zhao, Longyue and Wang, Yan (2009). China's pattern of trade and growth after WTO accession: Lessons for other developing countries. Journal of Chinese Economic and Foreign Trade Studies, Vol. 2, Iss: 3, $178-210$. 